\title{
A krónikus vesebetegek transzplantációval kapcsolatos attitüdjeinek vizsgálata
}

\author{
Illés Amanda ${ }^{1}$ - Nemes Balázs dr. ${ }^{2}$ - Kovács Sándor dr. ${ }^{3}$ - Bugán Antal ${ }^{1}$ \\ Debreceni Egyetem, ${ }^{1}$ Népegészségügyi Kar, Magatartástudományi Intézet, \\ ${ }^{2}$ Általános Orvostudományi Kar, Sebészeti Intézet, Szervtranszplantációs Nem Önálló Tanszék, \\ ${ }^{3}$ Gazdaságtudományi Kar, Ágazati Gazdaságtan és Módszertani Intézet, \\ Kutatásmódszertan és Statisztika Tanszék, Debrecen
}

\begin{abstract}
A vesetranszplantációhoz való viszony jelentősen befolyásolja a vesebetegek döntését a jobb életminőséget biztosító kezelés elfogadásában. Célunk a vesebetegek érzelmi-kognitív viszonyainak feltárása az egyes betegségstádiumok mentén. Vizsgálatunk 285 vesebeteg bevonásával készült. A vesebetegeknek három alcsoportját különítettük el: predializáltak, dializáltak és transzplantáltak. Elővizsgálatunk során egy 85 itemből álló attitüdkérdőívet alakítottunk ki, amelynek segítségével leírhattuk a betegeknek a betegségükhöz való kognitív-érzelmi viszonyulását. A transzplantáció előtt álló betegek körében a transzplantációval kapcsolatos negatív attitüdök jelentek meg. Ezzel szemben a már mútéten átesett betegek a veseátültetésről kifejezetten pozitívan vélekedtek. Sok beteg elutasítja a transzplantációt, ami összefüggést mutat a betegséggel és gyógyulással kapcsolatos attitűdökkel. Eredményeink azt mutatják, hogy a vesebetegek kognitív-érzelmi viszonyainak feltárása az orvosi diagnózis mellett jobb adherencia kialakítását teszi lehetôvé, segíthet a jobb életminőséget biztosító vesepótló kezelés elfogadásában.
\end{abstract}

Orv Hetil. 2018; 159(46): 1898-1904.

Kulcsszavak: vesetranszplantáció, attitűdvizsgálat

\section{Examination of attitudes towards transplantation among patients with chronic renal failure}

\begin{abstract}
The patients' attitudes towards kidney transplantation are significantly affected by the acceptance of the treatment to have a better quality of life. Exploration of the cognitive-emotional relation in patients with chronic renal failure. Our study included 285 kidney patients. We investigated three groups of patients: predialysis, dialysis and transplantation patients. In the framework of a pre-examination we have created an attitudinal questionnaire ( 85 items) that can be used to describe the cognitive and emotional attitude of kidney patients towards their illness and to measure scales. Negative attitudes towards transplantation were reported in dialysis and predialysis patients. In contrast, patients who had already undergone surgery were particularly positive about kidney transplantation. Many patients refuse transplantation which correlates with attitudes towards illness and healing. Our results showed that the exploration of the patients' cognitive emotional relation along with the medical diagnosis would have a better adherence towards the kidney substitutional treatment which ensures a better quality of life.
\end{abstract}

Keywords: kidney transplantation, attitude study

Illés A, Nemes B, Kovács S, Bugán A. [Examination of attitudes towards transplantation among patients with chronic renal failure]. Orv Hetil. 2018; 159(46): 1898-1904.

(Beérkezett: 2018. augusztus 24.; elfogadva: 2018. szeptember 15.) 
A krónikus vesebetegség világszerte jelentős népegészségügyi probléma. Magyarországon a krónikus, múvesekezelésre szoruló betegek száma - az iparosodott világhoz hasonlóan - évről évre növekszik. Mindemellett a transzplantációs listán szereplő betegek a végstádiumú vesebetegségben szenvedők kisebb hányadát jelentik, ami világméretű problémaként jelenik meg [1].

A hazai programok fejlődésnek indultak ugyan - egyre több transzplantációt végeznek, és emelkedik az élődonoros veseátültetések száma is -, azonban a transzplantáció számos előnye ellenére sok beteg még mindig a dialízisen való maradást választja. Ahhoz, hogy a fejlődő orvostudománnyal lépést tartva egyre több beteg kaphassa meg a számára legmegfelelőbb, egyénre szabott kezelést, fontos felmérni a betegek viszonyulását, attitüdjeit a különböző eljárások kapcsán. Ezáltal feltérképezhetők azok a tényezők, amelyek mentén a leginkább segíthetünk a beteg döntéshozatalában úgy, hogy az a legjobb életminőséggel járó gyógyulás útjának választásához vezessen.

A krónikus vesebetegségben szenvedő betegek állapota idővel progrediál, így a végstádiumban vesepótló kezelésre kerül sor. Számos betegnek kétségei vannak a veseátültetéssel kapcsolatban. A jelenség hátterében pszichológiai tényezók, a transzplantációval kapcsolatos hiedelmek, érzések húzódnak meg. Landreneau és mtsai felhívták a figyelmet arra, hogy a megfelelő kezelés megválasztását célzó döntéshelyzet vizsgálata hiányos a szakirodalmat tekintve, szükségessége azonban vitathatatlan [2]. Nagyon kevés az információ a predialízis időszakából a vesepótló kezelés megválasztásával kapcsolatos döntést befolyásoló tényezők és a vesepótló kezelésekkel kapcsolatos attitűdök tekintetében [3], holott a betegek transzplantációval kapcsolatos nézete a várólistára kerülés erős prediktora [4]. A preemptív transzplantáció kedvezőbb beteg- és grafttúlélést eredményez [5, 6], így az attitűdöknek a predialízis időszakában történő felmérése és korrigálása célszerú.

Landreneau a vizsgálatában azt találta, hogy a transzplantáció elutasításának hátterében kiemelt szerepe van a beteg félelmének és a sikertelen esetekkel való találkozásnak, s azt is számos szakirodalom támasztja alá, hogy a páciensek ismeretei gyakran tévesek, orvosilag pontatlanok [2]. Több közlemény is beszámol arról, hogy a recipiensek nagy része elutasítja az élődonoros transzplantáció lehetőségét, aminek fó motívumai a másik fél iránti aggodalom, a búntudat és az eladósodás kínzó érzete [7].

Vámos és mtsai dializált betegekkel végzett vizsgálatukban azt találták, hogy a transzplantációt elutasítók a veseátültetést követően kedvezőtlen egészségi állapotra számítanak, és több téves információval is rendelkeznek [8].

A téma fontossága ellenére a nemzetközi irodalomban is kevés vizsgálat áll rendelkezésre a betegek attitűdjeinek felméréséről, holott a betegséggel kapcsolatos vélekedések a mortalitás előrejelzői is, s ezen tudati tényezők hatása a kimenetel szempontjából hasonló erôsségű, mint a klinikai paraméterek és a komorbiditás [9].

A jelen tanulmányban beszámolunk az általunk végzett, krónikus vesebetegségben szenvedő betegek pszichológiai szempontú vizsgálatának egyes eredményeiről. A betegség különböző stádiumaiban lévő betegeket érintő attitüdvizsgálat tapasztalatait korábbi értekezésünkben foglaltuk össze [10]. Tanulmányunkban bemutatjuk a krónikus vesebetegségben szenvedő betegeknek a különböző vesepótló kezelésekkel kapcsolatos nézeteit, tudattartalmait, amelyek mentén leírjuk a transzplantáció mellett való döntés akadályait, a jelenlegi legoptimálisabb kezelési eljárás elutasítását magyarázó érzelmeket, hiedelmeket.

\section{Módszer}

A kérdőívek válaszainak statisztikai feldolgozását az SPSS for Windows 20.0.0 (IBM Corporation, Armonk, NY, Amerikai Egyesült Államok) felhasználásával végeztük.

Vizsgálatunk első lépéseként a transzplantációval szembeni attitûdök mérésére alkalmas kérdőívünket dolgoztuk ki. Félig strukturált interjúkkal tártuk fel a krónikus vesebetegek vélekedéseit, melyek narratív anyagának tartalomelemzését követően szerkesztettük meg attitűdkérdőívünket. Az általunk kidolgozott attitűdkérdőív 85 itemen keresztül méri a betegek transzplantációval szembeni attitüdjét. Kérdőívünk kidolgozásának menetét és annak eredményeit korábbi tanulmányunkban ismertettük [11].

Az elővizsgálat során kialakított kérdőívünket a fơvizsgálatunkban három almintán alkalmaztuk. Elkészítettük a közös és a betegségcsoportok között eltérő attitűdkérdések faktorstruktúráját, s ennek mentén két faktorszerkezetet alkottunk. A betegségkarrier leírásához diszkriminanciaanalízissel hasonlítottuk össze a csoportokat.

\section{Vizsgálati minta}

Kutatásunkat dialízisközpontokban (10. Sz. B. Braun Avitum Dialízisközpont, Debrecen; FMC Dialízis Center, Ózd; 2. Sz. B. Braun Avitum Dialízisközpont, Nyíregyháza), nefrológiai ambulanciákon, illetve a Debreceni Egyetem Sebészeti Intézetének Transzplantáció Központjában krónikus vesebetegek körében folytattuk.

Mintánkat három almintára osztottuk:

I. Predializált betegek.

II. Dializált betegek (peritonealis/hemodialízis kezelés alatt állók).

III. Transzplantált betegek (kadáver/élő donoros transzplantáción átesett beteg).

Vizsgálatunkban 285 vesebeteg vett részt (99 predializált, 99 dializált, 87 transzplantált). Fontosnak találtuk, hogy a betegek ne az ambuláló szakorvos szelektálása alapján kerüljenek vizsgálati mintánkba, ezért minden potenciális vesebeteggel kitöltöttük tesztbattériánkat. Ezáltal vizsgálati mintánk nem a potenciálisan transz- 


\begin{tabular}{ll}
\hline A vesepótló kezelés formája & $\mathrm{n}(\%)$ \\
\hline Predializált & $99(35)$ \\
Dializált & $99(35)$ \\
$P d$ & $10(10)$ \\
$H d$ & $89(90)$ \\
Transzplantált & $87(30)$ \\
$\quad$ Kadáver donoros & $81(93,1)$ \\
Élódonoros & $6(6,9)$ \\
\hline
\end{tabular}

Hd = hemodialízis; $\mathrm{Pd}=$ peritonealis dialízis

plantációra alkalmas betegekből került leírásra. Felmérésünkben a krónikus vesebetegek általános véleményére voltunk kíváncsiak, s feltevésünk szerint az eredményeket meghamisította volna a preszelekció.

A dializáltak többsége hemodialíziskezelést kap, mindössze tíz beteg választotta a hasi dialízis lehetőségét. A betegek évek óta vesepótló kezelésre járnak. A transzplantáltak többsége kadáver donoros veseátültetésen esett át. A vesebetegek a kadáver donoros transzplantációt előnyben részesítik, s a szakirodalmi adatokkal egyezően, az élődonoros transzplantációt a betegek kevésbé választják (1. táblázat). A betegek átlagéletkora 54 év, a nemek megoszlása arányos (128 nő, 157 férfi). Kérdőíveinket főként alap- és középfokú iskolát végzett betegek töltötték ki. A munkaviszony tekintetében a legnagyobb arányban a rokkantnyugdíjas betegek vettek részt kutatásunkban, mintánk közel 50\%-át képviselték. A három betegcsoport között a nemek tekintetében lényeges eltérés nem adódott, azonban a foglalkozási forma és az iskolai végzettség mentén szignifikáns eltolódást találtunk.

A predializáltak csoportjában magasabb volt a nyugdíjasok és a teljes munkaidőben dolgozók aránya, a rokkantnyugdíjasok száma viszont alacsonyabb. A transz- plantáltak körében a részmunkaidóben dolgozók voltak nagyobb számban. Emellett a transzplantált betegcsoport résztvevői között magasabb arányban szerepeltek az érettségivel rendelkezők, s relatíve alacsonyabb volt az általános iskolát végzett és a szakmunkás-végzettségü betegek száma (2. táblázat).

\section{A vizsgálat eredményei}

\section{A betegstádiumok leírása}

3. táblázat |A diszkriminanciaanalízissel alkotott faktorok szignifikáns* dif ferenciáló hatásának bemutatása az egyes betegstádiumok között

\begin{tabular}{|c|c|c|c|}
\hline Faktor & Predializált ${ }^{\star \star}$ & Dializált $^{\star \star}$ & $\begin{array}{l}\text { Transzplan- } \\
\text { tált }^{\star \star}\end{array}$ \\
\hline $\begin{array}{l}\text { A transzplantációs } \\
\text { gyógyítás iránti } \\
\text { bizalmatlanság }\end{array}$ & 0,225 & 0,050 & $-0,314$ \\
\hline A mútéttől való félelem & 0,189 & 0,074 & $-0,300$ \\
\hline $\begin{array}{l}\text { Az énrészesség vállalása } \\
\text { a gyógyulásban }\end{array}$ & $-0,269$ & $-0,249$ & 0,591 \\
\hline Az új vese elfogadása & $-0,249$ & 0,100 & 0,170 \\
\hline $\begin{array}{l}\text { A dialízis szubjektív } \\
\text { betegségterhe }\end{array}$ & $-0,010$ & $-0,303$ & $-0,280$ \\
\hline A gyógyulásba vetett hit & 0,391 & $-0,386$ & 0,005 \\
\hline $\begin{array}{l}\text { Az új vesének való } \\
\text { kiszolgáltatottság }\end{array}$ & $-0,010$ & 0,252 & $-0,280$ \\
\hline $\begin{array}{l}\text { Az új vese befogadásá- } \\
\text { ban való énrészesség } \\
\text { tagadása }\end{array}$ & $-0,111$ & 0,333 & $-0,251$ \\
\hline
\end{tabular}

${ }^{*} \mathrm{p}<0,01$

**A diszkriminanciafüggvény együtthatói

\section{Predializált betegek}

A predializált betegek körében kifejezetten negatín attitüddel találkoztunk a transzplantációt illetően. Esetük-

2. táblázat |A vizsgálati minta szociodemográfiai tényezők mentén történő leírása

\begin{tabular}{llllll}
\hline & \multicolumn{1}{c}{ A vesepótló kezelés formája } & $\begin{array}{l}\text { Összes } \\
(\mathrm{n} / \%)\end{array}$ & $\begin{array}{l}\text { Predializált } \\
(\mathrm{n} / \%)\end{array}$ & $\begin{array}{l}\text { Dializált } \\
(\mathrm{n} / \%)\end{array}$ & $\begin{array}{l}\text { Transzplantált } \\
(\mathrm{n} / \%)\end{array}$ \\
\hline \multirow{2}{*}{ Nem } & \multicolumn{1}{l}{ Nó } & $128(45)$ & $47(47,5)$ & $43(43,9)$ & $38(43,7)$ \\
\cline { 2 - 6 } & Férfi & $157(55)$ & $52(52,5)$ & $55(56,1)$ & $49(56,3)$ \\
\hline \multirow{2}{*}{ Foglalkozási forma } & Munkanélküli & $6(2,1)$ & $2(2,2)$ & $3(3,2)$ & $1(1,2)$ \\
\cline { 2 - 6 } & Nyugdíjas & $84(29,5)$ & $41(44,1)$ & $26(27,7)$ & $17(20,7)$ \\
\cline { 2 - 6 } & Rokkantnyugdíjas & $125(43,9)$ & $28(30,1)$ & $56(59,6)$ & $43(52,4)$ \\
\cline { 2 - 6 } & Teljes munkaidő & $38(13,3)$ & $17(18,3)$ & $3(3,2)$ & $10(12,2)$ \\
\cline { 2 - 6 } & Részmunkaidő & $20(7)$ & $5(5,4)$ & $6(6,4)$ & $11(13,4)$ \\
\hline \multirow{2}{*}{ Iskolai végzettség } & Általános iskola & $64(22,5)$ & $25(25,3)$ & $24(24,2)$ & $15(17,2)$ \\
\cline { 2 - 6 } & Szakmunkásképzó & $84(29,5)$ & $29(29,3)$ & $38(38,4)$ & $17(19,5)$ \\
\cline { 2 - 6 } & Szakközépiskola/gimnázium & $94(33)$ & $29(29,3)$ & $22(22,2)$ & $43(49,4)$ \\
\cline { 2 - 6 } & Főiskola/egyetem & $43(15)$ & $16(16,2)$ & $15(15,2)$ & $12(13,8)$ \\
\hline
\end{tabular}


ben az eljárás mögött meghúzódó félelem és szorongás növeli a veseátültetéssel szembeni bizalmatlanságot, s egyben távol tartja a gyógyulásukban való személyes felelősség, azaz az énrészesség vállalását is. Mindez megakadályozza a várólistára kerülés meghozataláról való döntést. A predializáltak még nem élték át a betegségük előrehaladtával megjelenő dialíziskezelés életminőségkorlátozó élményét, így számukra hárítható a vesetranszplantációs mütétre vonatkozó döntés, kevésbé tudják átélni a transzplantáció nyújtotta lehetőségeket, az életminőség jelentős javulásának ígéretét. A transzplantáció félelemmel teli jövőképet hordoz, így kevésbé tudnak azonosulni a jövőben rájuk háruló döntési helyzettel, ezért az új vese elfogadása is gátolt, ôk fogadják el a legkevésbé annak gondolatát, hogy egy idegen szerv kerüljön a testükbe. A félelemmel teli jövókép okozta szorongás következtében a dializis szubjektív betegségterhe esetükben a legmagasabb. Betegségük tünetei még nem okoznak jelentős mértékü objektív terhet, de a betegségkarrierjükben megjelenő jövőkép (dialízis, transzplantáció) okozta félelem és szorongás a szubjektív betegségteherben nyilvánul meg. Még reménykednek, hogy a félelmet okozó kezelések nélkül is meggyógyulhatnak, így a gyógyulásban való hitük irreális módon megemelkedik.

\section{Dializált betegek}

A betegséghez és a gyógyuláshoz való viszonyulást illetően a dializált betegeknél is negatív attitüddel találkoztunk. Egyre közelebb kerül a transzplantáció gondolata a dializált beteg számára, s az ezzel kapcsolatos félelem az új vesének való kiszolgáltatottság attitüdjében manifesztálódik, mely magában hordozza az új vesével kapcsolatos aggodalmakat. A megélt kiszolgáltatottság és korlátozottság érzését az új szerv beültetésével hozzák összefüggésbe.

A dializált betegek a vesepótló kezelés függőiként a mindennapos korlátozottság mellett annak életmentő funkcióját élik meg. Ha nem kapnak kezelést, életveszélyes állapotba kerülnek. Az ambivalenciákkal átszőtt krízishelyzettel szembesülve a gyógyulással kapcsolatos bizalmatlanságuk jelenik meg. Már elvesztették a gyógyulásban való hitüket, s reménytelenségük kerül előtérbe, melynek következtében a korlátokat okozó, ám a létfenntartásukhoz nélkülözhetetlen dializis eljárását kevésbé negatívan festik le. Ezzel együtt tagadják a gyógyulásukban vállalt felelősségüket, énrészességüket. Mindennek magyarázatául szolgálhat a kognitív disszonancia redukciójának elve is: megélt állapotuknak a valósághoz mért kognitív értékelése irracionálisan megnő, vagyis a dialízis negatív hatását elfojtják, életmentő pozitív jelentőségét pedig felértékelik, ezzel racionalizálva a transzplantáció elutasítását.

\section{Transzplantált betegek}

A transzplantált betegek körében kifejezetten pozitín attitüddel találkoztunk. A betegek életében a korábbi szorongásos elképzeléseik valós feladatokká és kihívássá váltak, így a transzplantáció élményszintü megélése következtében már vállalják a gyógyulásukban való szerepüket, felelősségüket a saját gyógyulásukban, s érdekeltek az új vese elfogadásában is. A betegségkarrier korábbi szakaszaiban a betegek kevésbé fogadják el azt, hogy idegen szerv kerüljön a testükbe. Az új szervvel való együttélés azonban már nem a fantáziában felnagyított szubjektív tartalomként jelenik meg, hanem maga a transzplantáció realitássá válik. A megfelelő egészségi állapot megőrzése valós elvárásként és feladatként jelenik meg, nem pedig a fantáziában szereplő szorongásteli tartalomként. Mindezzel magyarázható, hogy az új vese befogadásában való énrészesség tagadása, illetve az új vesének való kiszolgáltatottság esetükben a legkisebb mértékben van jelen. A veseátültetésről egyértelmüen pozitívan gondolkodnak, bizalmatlanságuk mérséklődik, s hisznek a gyógyulásukban. A korábbi ambivalens érzések erejüket vesztik, s az eljárás már nem az ismeretlen jövő része, hanem a múltban megtörtént tapasztalás. Ennek következtében a veseátültetés félelemmel és szorongással töltött tartalma jelentősen csökken.

\section{A transzplantáció választása és elutasítása}

Vizsgálati eredményeink szerint az általunk vizsgált 198, transzplantáció előtt álló beteg egyharmada elutasitja a veseátültetést ( $\mathrm{n}=67$ fö, 33,3\%). A transzplantációt választók $(\mathrm{n}=134$ fó, 66,7\%) többsége $(\mathrm{n}=78$ fó, $57,8 \%)$ a kadáver donoros veseátültetést preferálta, azonban sok beteg ( $\mathrm{n}=56$ fó, $42,03 \%$ ) számolt be arról, hogy az élődonoros transzplantációt választaná.

A transzplantáció elutasítása a leginkább a dializáltak körében jelenik meg: a dializált betegek mindössze 47\%-a ( $\mathrm{n}=48$ fó) nyilatkozott arról, hogy a dialízisról a transzplantációra áttérne, $48 \%$-uk $(\mathrm{n}=49$ fó) nem változtatna a kezelés módján.

Ez alapján megállapítható, hogy a vesebetegek dialízis melletti döntésével a páciens attitűdje negatív irányba tolódik a vesetranszplantációt illetően. A transzplantáció elutasítása megjelenik a betegek várólistán való szereplésének alacsony arányában is: vizsgálati mintánkban a transzplantáció előtt álló betegeknek $(\mathrm{n}=198)$ csupán a $17 \%-a(n=34)$ szerepel a transzplantációs várólistán.

A predializált és a dializált betegek elutasító véleménye szemben áll a transzplantációs mütéten átesett betegcsoport $(\mathrm{n}=87)$ tapasztalatával, akiknek a többsége $(94,3 \%, n$ =82) sikeresnek itéli a veseátültetést. Ahogy a beteg közelebb kerül a veseátültetés választásának lehetôségéhez, az élődonoros transzplantáció elutasítása is egyre inkább megjelenik tudatában. Míg a predializáltak 40\%-a választaná az élödonoros transzplantációt, addig a dializáltaknál ez az arány már 28,3\%-ra csökken.

Az élődonoros transzplantáció preferálása csupán fantáziában jelenik meg a vesebetegek körében addig, amíg nincs realitása a transzplantáció mellett való elköteleződésnek. Ezt igazolja az is, hogy a transzplantált betegek 
közül mindössze hat fó kapta élö donortól a beültetett veséjét.

A transzplantáció elutasításának hátterében álló okok feltárásához megvizsgáltuk a betegek vesepótló kezeléssel kapcsolatos ismereteit is. A betegek téves információi megjelentek eredményeinkben, ami leginkább a várólistára való kerülés folyamatát érinti: sok beteg (foóként a predializált betegek) úgy véli, hogy csak a dialízist követően lehet a várólistára kerülni (4. táblázat).

A transzplantáció elutasításának/elfogadásának hátterében álló okok feltárása során kitértünk a transzplantációval szembeni attitüdök vizsgálatára is. Eredményeink alapján a transzplantáció melletti elköteleződést segíti a betegnek a transzplantációs gyógyitásba vetett hite, a gyógyulás okozta hátrányokkal való megbékélése és a gyógyulásban való énrészesség vállalása. A transzplantáció elutasításával együttjárást mutatott a transzplantációs gyógyitás iránti bizalmatlanság és a transzplantáció elutasitása a donor személyén keresztül faktor (5. táblázat).

Tehát a donor személyével kapcsolatos érzések kulcsfontosságú szerepet játszanak a transzplantáció elutasításában, a donor személyével kapcsolatban megjelenő emóciók gátolhatják a transzplantáció választásának szándékát.

4. táblázat |A vesebetegek transzplantációval kapcsolatos hiedelmeinek bemutatása

\begin{tabular}{llc}
\hline \multicolumn{3}{l}{ „Úgy tudom, csak az kerülhet fel a transzplantációs várólistára, aki } \\
dialízisre jár.”
\end{tabular}

5. táblázat A diszkriminanciaanalízissel alkotott faktorok szignifikáns* differenciáló hatásának bemutatása a transzplantációt választó és nem választó betegek között

\begin{tabular}{lcc}
\hline Faktor & Választja** $^{* *}$ & Nem választja** \\
\hline $\begin{array}{l}\text { A transzplantációs gyógyításba } \\
\text { vetett hit }\end{array}$ & 0,216 & $-0,371$ \\
$\begin{array}{l}\text { A transzplantáció elutasítása } \\
\text { a donor személyén keresztül }\end{array}$ & $-0,157$ & 0,557 \\
$\begin{array}{l}\text { A transzplantációs gyógyítás iránti } \\
\text { bizalmatlanság }\end{array}$ & $-0,165$ & 0,835 \\
$\begin{array}{l}\text { A gyógyulás okozta hátrányokkal } \\
\text { való megbékélés }\end{array}$ & 0,256 & $-0,339$ \\
$\begin{array}{l}\text { Az énrészesség vállalása } \\
\text { a gyógyulásban }\end{array}$ & 0,017 & $-0,793$ \\
\hline
\end{tabular}

${ }^{*} \mathrm{p}<0,001$

**A diszkriminanciafüggvény együtthatói

\section{Megbeszélés}

Vizsgálatunkban különböző stádiumban lévő vesebetegeket hasonlítottunk össze. A betegek attitúdjeinek, a transzplantációra vonatkozó nézetrendszereinek feltárásához kérdő́ivet dolgoztunk ki. A kérdőív alkalmas a krónikus vesebetegek általános attitüdjeinek leírására, valamint a predializált, dializált és transzplantált betegcsoportok jellemzőinek mérésére.

Függetlenül attól, hogy a betegek melyik stádiumban vannak, foglalkoztatja őket a mütét gondolata, a transzplantáció lehetősége. Ugyanakkor mind a gyógyító eljárások elfogadását, mind az orvos iránti bizalom érzését ambivalenciák övezik. Az ambivalenciák kivetülnek az elképzelt donor személyére, így megjelenik a donor személye iránti érdeklődés kíváncsiság vagy egyéb (például bűntudat) érzelem formájában, amely a transzplantációs gyógyítás választásához kapcsolódóan szorongást, esetleg annak elutasítását okozhatja. Vizsgálati tapasztalataink megerősítik azoknak a korábbi nemzetközi vizsgálatoknak az eredményeit, melyek feltárták, hogy a betegeket foglalkoztatja a szerv eredete, és azt, hogy gyakran büntudattal viszonyulnak a donorhoz [12-14]. A predializált betegek azok, akik a legkevésbé fogadják el annak gondolatát, hogy idegen szerv kerüljön a szervezetükbe. Mindez egybeesik Hans és mtsai eredményeivel. Hans és mtsai beszámoltak arról, hogy a transzplantációt megelőzően a betegek sokkal inkább vallják, hogy veseátültetést követően a beültetett szerv idegenként él tovább a szervezetükben. Vizsgálatukban a már operáción átesett betegek sokkal kisebb fokú idegenségérzetről számoltak be a beültetett szervükkel kapcsolatban, mint azok, akik még a betegségkarrier első stádiumában voltak [15].

A gyógyulást/gyógyítást illetôen a predializált és a dializált betegeknél egyaránt negatív attitüddel találkoztunk. A predializált betegek bizalmatlanok a transzplantációs gyógyítással szemben, s képtelenek elfogadni a tényt, hogy idegen szerv legyen a testükben, emellett félnek a műtéti eljárástól. Alapvetően hisznek a betegségük gyógyulásában, s hárítják a gyógyulásukkal kapcsolatos saját szerepüket, felelősségüket. A dializált betegek attitűdjében a leginkább a kiszolgáltatottság és a reménytelenség érzése dominál: lemondanak gyógyulásukról, elveszítették a gyógyulásukban való hitüket, s a dialízis hátrányaival is részben megbékéltek. Reménytelenségükből adódóan kételyeik vannak annak kapcsán, hogy saját sorsukba beleszólásuk lehet, ezért saját felelősségüket, szerepüket tagadják gyógyulásuk vonatkozásában. A reménytelenség ismert kockázati tényező, számos szakirodalom alátámasztja a depresszióval és öngyilkossággal való összefüggését [16]. Mindemellett a betegek által megélt reménytelenség akadályozza az orvosi előírásokkal való együttmúködést, mely a veseelégtelen betegeknél az egyik legkockázatosabb tényező a gyógyulásuk tekintetében [17]. A dializált betegek körében jelentős pszichés hanyatlást tapasztaltunk, mely érinti a fent emlí- 
tett betegséggel és gyógyulással kapcsolatos attitűdök mellett a depresszív tüneteket, illetve a betegségből adódó korlátozottságot is: korábbi eredményeink alapján a dializáltak körében találtuk a legmagasabbnak a depreszszió és a betegségteher mértékét [10], mely eredményünk közel egybeesik a Novák és mtsai által dializáltaknál mért adatokkal [18].

A transzplantált betegek körében kifejezetten pozitív attitűdökkel találkoztunk. A transzplantált betegek alapvetően hisznek a gyógyulásukban, elfogadással viszonyulnak a beültetett új veséjükhöz, és vállalják a gyógyítási folyamatban betöltött saját szerepüket, felelősségüket. Többségük sikeresnek ítéli a veseátültetést, s az új vese iránti elvárásaikban legalább 10 éves müködést feltételeznek. A transzplantációs mútét egyértelmüen pozitív irányban módosítja a betegeknek a betegségükkel kapcsolatos attitűdjeit, emellett a transzplantáción átesett betegek esetén a depresszió aránya is csökken a korábbiakhoz képest [10].

Jelen tanulmányunk rámutat, hogy a transzplantációról szóló hiedelmek, elképzelések összefüggést jeleznek a veseátültetés elutasításával. Eredményeink alapján a transzplantáció választása mögött a gyógyításban való hit fontos szerepet játszik. Azok a betegek, akik hisznek a transzplantációval történő gyógyításban, szívesebben vállalják a veseátültetést. Mindez együttjárást mutat a transzplantáció iránti bizalom kérdésével, mely a transzplantáció választásához nélkülözhetetlen tényező.

A betegek hajlamosak a saját felelősségüket negálni a gyógyulásuk tekintetében, ami a transzplantáció elutasításához vezethet. Azok a betegek, akik hajlandóak vállalni a gyógyulásban betöltött szerepüket, felelősségüket, s egyben képesek arra, hogy megbékéljenek a kezelés okozta hátrányokkal, kitartanak a transzplantáció választása és vállalása mellett. A transzplantáció elutasítása mögött több esetben a donor személyével kapcsolatosan megélt érzelmek állhatnak.

Korábbi kutatások feltárták, hogy a betegeket foglalkoztatja a szerv eredete, igénylik, hogy a donorról többet megtudjanak. Több vizsgálat beszámol arról, hogy a betegek az elhunyt donorral kapcsolatosan büntudatot élnek meg, s frusztrálja őket annak gondolata, hogy egy halott ember szerve múködik a testükben, akinek meg kellett halnia ahhoz, hogy ők életben maradhassanak [12]. A beültetett szerv nemcsak immunológiailag, hanem pszichésen is idegen, vagyis a sikeres átültetéshez nélkülözhetetlen egyfajta pszichés transzplantáció is. Kadáverszerv-átültetés esetén a donor személye ismeretlen marad, így ahhoz, hogy a páciens integrálja önmagába, szükséges, hogy elfogadja azt a tényt, hogy idegen szerv került a testébe. A pszichés integráció részeként a beteg az idegennek érzett testrészt oly módon igyekszik beépíteni [19], hogy a beültetett szervet mentális reprezentációval ruházza fel [20]. Ehhez első lépésként tudattalan fantáziákkal szállja meg a donort [21].

Vizsgálatunk rámutat a krónikus vesebetegek részére nyújtandó pszichológiai segítségnyújtás fontosságára.
A betegek körében szülkséges a felelősségvállalás fejlesztése, a gyógyításban való hit erősítése mellett a vesetranszplantációt követő hátrányok elfogadásában való segítségnyújtás, illetve a donor személyével való pszichés munkavégzés. Emellett a transzplantáció előtt álló betegek számára nélkülözhetetlen a transzplantációs eljárással szembeni bizalom kiépítése.

Anyagi támogatás: A közlemény megírása anyagi támogatásban nem részesült.

Szerzôi munkamegosztás: I. A.: PhD-kutatás - a kutatás lebonyolítása, adatgyüjtés. N. B.: A résztvevők biztosítása, a betegek kiválasztása, sebészi konzultáció, társtémavezetés. K. S.: Statisztikai feldolgozás. B. A.: Kérdőívkialakítás, pszichológiai módszertan, témavezetés. A cikk végleges változatát valamennyi szerző elolvasta és jóváhagyta.

Érdekeltségek: A szerzőknek nincsenek érdekeltségeik.

\section{Irodalom}

[1] Járay, J, Hidvégi M. Results of Hungarian renal replacement therapy. [Hazai vesepótló kezelések eredményei.] Hyperton Nephrol. 2001; 5: 244-270. [Hungarian]

[2] Landreneau K, Ward-Smith P. Perceptions of adult patients on hemodialysis concerning choice among renal replacement therapies. Nephrol Nurs J. 2007; 34: 513-519.

[3] Chanouzas D, Ng KP, Fallouh B, et al. What influences patient choice of treatment modality at the pre-dialysis stage? Nephrol Dial Transplant. 2012; 27: 1542-1547.

[4] Ayanian JZ, Cleary PD, Weissman JS, et al. The effect of patients' preferences on racial differences in access to renal transplantation. N Engl J Med. 1999; 341: 1661-1669.

[5] Meier-Kriesche HU, Port FK, Ojo AO, et al. Effect of waiting time on renal transplant outcome. Kidney Int. 2000; 58: 13111317.

[6] Kasiske BL, Snyder JJ, Matas AJ, et al. Preemptive kidney transplantation: the advantage and the advantaged. J Am Soc Nephrol. 2002; 13: 1358-1364.

[7] Waterman AD, Stanley SL, Covelli T, et al. Living donation decision making: recipients' concerns and educational needs. Prog Transplant. 2006; 16: 17-23.

[8] Vamos EP, Csepanyi G, Zambo M, et al. Sociodemographic factors and patient perceptions are associated with attitudes to kidney transplantation among hemodialysis patients. Nephrol Dial Transplant. 2009; 24: 653-660.

[9] Kimmel PL, Peterson RA, Weihs KL, et al. Psychosocial factors, behavioral compliance and survival in urban hemodialysis patients. Kidney Int. 1998; 54: 245-254.

[10] Illés A, Bugán A, Kovács S, et al. Patient attitudes toward transplantation as preferred treatment modality in different stages of renal disease. Transplant Proc. 2017; 49: 1517-1521.

[11] Illés A, Nemes B, Zsom L, et al. Questionnaire development for the measurement of patients' attitudes toward renal transplantation. Transplant Proc. 2016; 48: 2534-2539.

[12] Quintin J. Organ transplantation and meaning of life: the quest for self fulfillment. Med Health Care Philos. 2013; 16: 565-574.

[13] Baines LS, Jindal RM. The struggle for life: a psychological perspective of kidney disease and transplantation. Praeger Publishers, Westport, CT, 2003. 
[14] Pascazio L, Nardone IB, Clarici A, et al. Anxiety, depression and emotional profile in renal transplant recipients and healthy subjects: a comparative study. Transplant Proc. 2010; 42: 35863590.

[15] Schlitt HJ, Brunkhorst R, Haverich A, et al. Attitude of patients toward transplantation of xenogeneic organs. Langenbecks Arch Surg. 1999; 384: 384-391.

[16] Perczel FD, Sallai J, Rózsa S. Psychometric analysis of Beck's Hopelessness Scale. [A Beck-féle Reménytelenség Skála pszichometriai vizsgálata.] Psychiatr Hung. 2001; 16: 632-643. [Hungarian]

[17] DiMatteo MR, Lepper HS, Croghan TW. Depression is a risk factor for noncompliance with medical treatment: meta-analysis of the effects of anxiety and depression on patient adherence. Arch Intern Med. 2000; 160: 2101-2107.

[18] Novak M, Mah K, Molnar MZ, et al. Factor structure and reliability of the Hungarian version of the Illness Intrusiveness Scale: invariance across North American and Hungarian dialysis patients. J Psychosom Res. 2005; 58: 103-110.

[19] Fukunishi I. Psychosomatic problems surrounding kidney transplantation. Psychother Psychosom. 1992; 57: 42-49.

[20] Csabai M, Erôs F. Boundaries of the body and the self. [Testhatárok és énhatárok.] Jószöveg Múhely, Budapest, 2000. [Hungarian]

[21] Consoli E. Person-centered approach in the medicine of organ transplants, 2012. Available from: http://www.psicoanalisi.it/ psicoanalisi/osservatorio/articoli/osservaingl132.htm

(Illés Amanda,

Debrecen, Pf. 400, 4002

e-mail: tyepkov@gmail.com)

\section{PÁLYÁZAT}

A Prof. Dr. Romics László Akadémikus Emlékére Alapítvány pályázatot hirdet Magyarországon dolgozó, magyar állampolgárságú, 40 éven aluli orvosok és orvosbiológiai kutatással foglalkozó személyek számára. A nyertes pályázó(k) között 500000 Ft alapítványi adomány kerül kiosztásra.

A pályázat célja: a klinikai gyógyítás vagy orvosi tudományos kutatás területén dolgozók kiemelkedő tudományos tevékenységének elismerése.

Előnyt élveznek azok a pályázók, akik az alapítvány névadójának munkásságát folytatva cardiovascularis és anyagcsere-betegségek területéről nyújtanak be pályázatot.

A pályázat benyújtásának határideje: 2019. január 31. (elbírálásának határideje: 2019. április 30.)

A pályázatot a palyazat@romicsalapitvany.hu e-mail címre pdf formátumban kell benyújtani.

A pályázatot természetes személy, saját nevében, magyar nyelven nyújthatja be, a pályázati anyag ábrák nélkül maximum 15000 leütés (karakter) terjedelmű lehet. A pályázathoz mellékelni kell egy rövid szakmai életrajzot a születési év megjelölésével.

A pályázat benyújtását saját kézzel aláírt és dátummal ellátott levélben kell bejelenteni az alapítvány titkárának címezve (a borítékra írandó cím: dr. Dudás Márta, 1461 Budapest, Pf 62.) könyvelt (ajánlott) küldeményben, mert ezen bejelentés alapján válik hitelessé a pályázat. A pályázatot nyomtatott formában nem kell mellékelni.

Az alapítvány adatairól, működéséről a www.romicsalapitvany.hu honlapon található információ.

A cikk a Creative Commons Attribution-NonCommercial 4.0 International License (https://creativecommons.org/licenses/by-nc/4.0) feltételei szerint publikált Open Access közlemény, melynek szellemében a cikk nem kereskedelmi célból bármilyen médiumban szabadon felhasználható, megosztható és újraközölhető, feltéve, hogy az eredeti szerző és a közlés helye, illetve a CC License linkje és az esetlegesen végrehajtott módositások feltüntetésre kerülnek. 